\title{
POSTURAL TONOGRAPHIC TEST FOR THE EARLY DIAGNOSIS OF GLAUCOMA*
}

\author{
BY \\ BRUNO BOLES CARENINI AND AGOSTINO MOLFINO \\ Department of Ophthalmology, University of Genoa
}

AMONG the various tests used in the early diagnosis of glaucoma the so-called provocative tests occupy an important place.

Numerous tests have been proposed, but their reliability on a statistical basis has only been studied in the case of some tests. Not all of these have given clinically satisfactory results, either on account of the variability of their results or of the inconvenience their application causes to the patient. It is considered that provocative tests have a high diagnostic importance, while the relatively small number of statistically reliable and clinically satisfactory tests makes any contribution to the subject of great interest.

During a tonographic study on normal subjects to determine variations of intraocular pressure, the outflow facility, and the aqueous production in various positions of the body, we were able to show that the inclined head-and-body-downward position $\left(-25^{\circ}\right)$ can induce a small but significant increase in ocular tension and a decrease in outflow facility (Boles Carenini and Molfino, 1961). Similar responses, but of greater degree, were found in glaucomatous subjects and in those patients in whom the characteristic changes of aqueous humour dynamics were beginning (Köllner, 1916; Tessier, 1930 a and b; Stroble and Follmann, 1936; and Scharf, 1952). For this reason some authors have suggested a study of the variations of intraocular pressure with varying positions of the body as a test for glaucoma (Köllner, 1916; Thibert, 1922; Thiel, 1925; Wegner, 1925; Stroble and Follmann, 1936; Caselli, 1954; Komoto, 1954; and Ebisawa, 1956). Others, although confirming tonometric variations (Leydhecker and Meinke, 1956), have denied their value in diagnosis (Leydhecker, 1955).

The purpose of the present research is to determine whether the tonographic findings in patients in the inclined head-downward position (Trendelenburg $-25^{\circ}$ ) would constitute a reliable test, showing variations of both the ocular tension and the outflow facility.

Before applying a provocative test it is necessary to study the reactions of the normal eye to the same test and to define the limits of the tensional increase caused by the test. 
The limits of physiological responses can be determined by studying a large number of normal subjects and by taking as the limits the highest values obtained or judging the results obtained in normal eyes by statistical methods, as in the method of Leydhecker (1955). This author takes into consideration, for each tested normal eye, the mean tension, namely, the tension before and after the test, and the maximum tension. Subsequently he calculates the average of the mean tensions $(M)$ of all the tested eyes and the standard deviation $(\delta)$. The probability of a tension increase of $\mathbf{M}+2 \delta$ being normal is still $0 \cdot 13$ per cent. Leydhecker therefore considers as probably pathological a tension increase of $\mathbf{M}+2 \delta+1 \mathrm{~mm}$. $\mathrm{Hg}$, and as definitely pathological a tension increase of $\mathbf{M}+3 \delta+1 \mathrm{~mm}$. $\mathbf{H g}$. The same statistical calculations are applied to the maximum readings reached after the test, considering as a possible upper limit in healthy eyes a value of $\mathbf{M}+3 \delta$ and as definitely pathological a value of $\mathbf{M}+3 \delta+1$.

The data with regard to maximum tensions are less reliable than those obtained from the mean tensions, because the maximum tension reached after the test depends on the level of the intra-ocular pressure before the test (Leydhecker, 1955).

\section{Methods}

Our test series comprised 100 healthy eyes from 50 normal subjects, aged between 20 and 60 years. On those eyes we have taken tonographic readings with the Mueller electronic tonometer in accordance with the accepted technique.

Before tonography the coefficient of ocular rigidity was calculated by the Friedenwald differential tonometric method and by the charts prepared by Moses and Becker (1958). Allowance was made for such a coefficient in the eye pressure determination as well as for the calculation of outflow facility; for the latter we have used the charts prepared by Ballintine (1954) for eyes with differing scleral rigidity.

On all subjects the tonography was performed with the patient in the supine position $\left(0^{\circ}\right)$ and inclined $25^{\circ}$ head-downwards $\left(-25^{\circ}\right)$. A surgical bed with special shoulder supports allowing the desired inclination was used. A fixation light was used to correct the position of the head and any deviation of the eye due to heterophoria. A period of at least twenty-four hours elapsed between the two tonographic examinations on the same subject, and for each subject the examinations were performed at the same hour. Before each tonography the subject remained in the chosen position for five minutes. Following the same procedure we have carried out tonography on 100 eyes affected by chronic simple glaucoma, in 73 patients who had not undergone surgical treatment and in whom all medical treatment had been interrupted for at least twenty-four hours. All the tested eyes presented tension not higher than $30 \mathrm{~mm}$. Hg because provocative tests are usually applied in eyes with such tensional values; the diagnosis of glaucoma in all the tested eyes was established by the results of tonometric curves, by tonographic studies, by campimetric and ophthalmoscopic examination, and by other provocative tests. The postural test was carried out during those hours of the day in which, as shown by the tonometric curves of the previous day, no spontaneous rise or fall of the ocular pressure occurred.

\section{Results}

The tonometric ṽalues obtained for the 100 normal eyes in the supine position (T1) and in the $-25^{\circ}$ position (T2), are related in Table I, which also shows the tensional difference $(\Delta)$ found in each eye between the two position. 


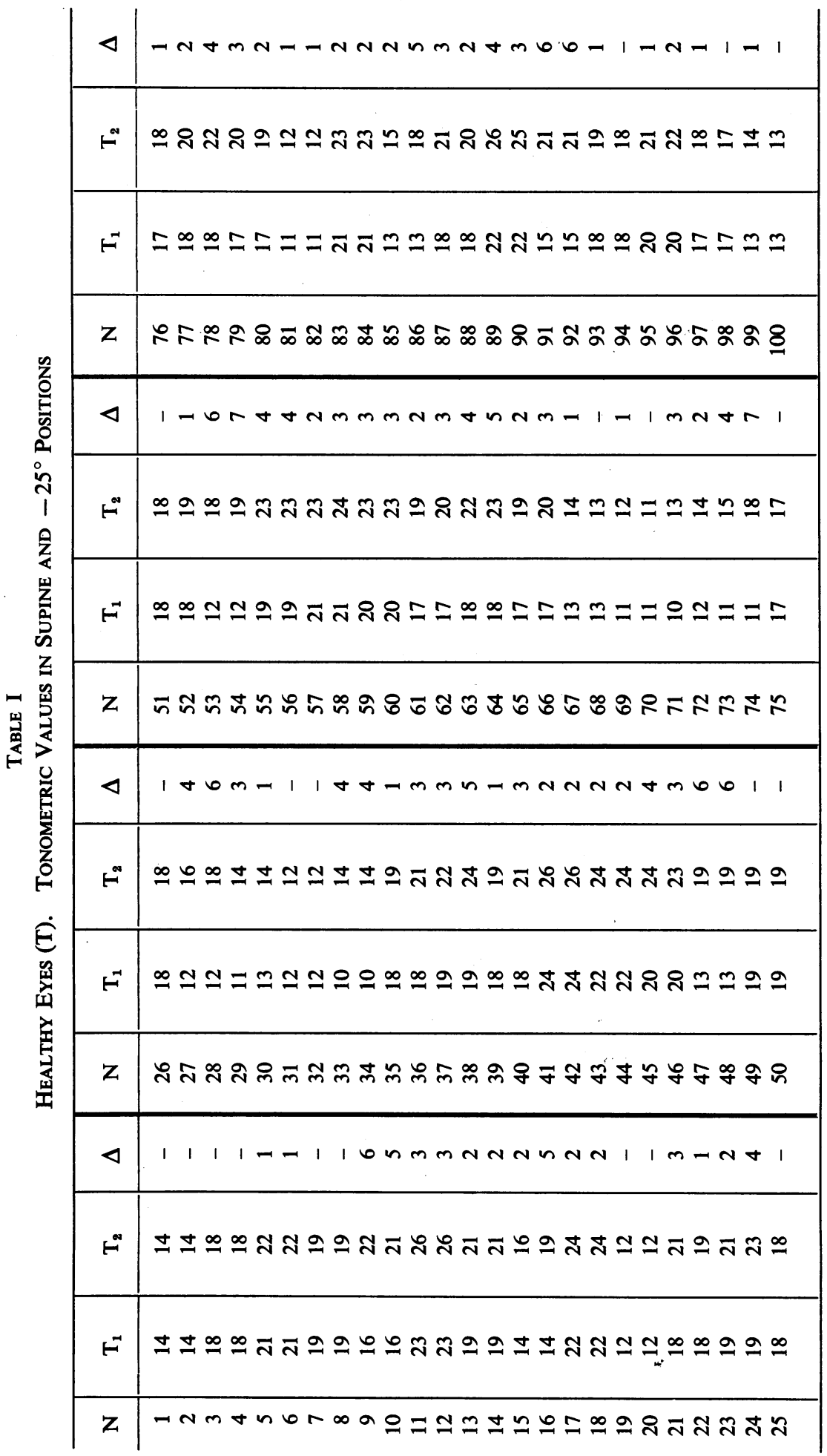


We have analysed such data in accordance with the above-mentioned method of Leydhecker (1955).

As indicated in Table II (which shows the values obtained from this statistical evaluation), the average tensional increase obtained in the two positions was $2.3 \mathrm{~mm}$. $\mathrm{Hg}$ with a standard deviation $(\delta)$ of $\pm 1 \cdot 9$.

TABLE II

Values ObTained from Statistical Evaluation

\begin{tabular}{c|c|c|c|c}
\hline No. of Tests & $\begin{array}{c}\text { Mean of } \\
\text { Increase of } \\
\text { Tension } \\
(\mathrm{mm} . \mathrm{Hg})\end{array}$ & $\begin{array}{c}\text { Standard } \\
\text { Deviation } \\
(\delta)\end{array}$ & $\begin{array}{c}\text { Probable } \\
\text { Pathological } \\
\text { Increase of } \\
\text { Tension } \\
(\mathrm{M}+2 \delta+1) \\
\mathrm{mm} . \mathrm{Hg}\end{array}$ & $\begin{array}{c}\text { Definite } \\
\text { Pathological } \\
\text { Increase of } \\
\text { Tension } \\
(\mathrm{M}+3 \delta+1) \\
\mathrm{mm} . \mathrm{Hg}\end{array}$ \\
\hline 100 & $2 \cdot 3$ & \pm 1.9 & $7 \cdot 1$ & $9 \cdot 0$ \\
\hline
\end{tabular}

The values of probable pathological increase and of definite pathological tensional increase are therefore $7 \cdot 1$ and $9.0 \mathrm{~mm}$. $\mathrm{Hg}$ respectively.

In Table III we relate the average value of intra-ocular tension after the test $(19 \cdot 1 \mathrm{~mm} . \mathrm{Hg})$ to the relative standard deviation $( \pm 4 \cdot 1)$ as well as the statistically calculated values of tension to be considered still possible in normal eyes after the test (ceiling) $(31.4 \mathrm{~mm} . \mathrm{Hg})$ and of definite pathological ceiling $(32 \cdot 4 \mathrm{~mm} . \mathrm{Hg})$.

TABLE III

Average Value of Intra-ocular Tension after Test

\begin{tabular}{c|c|c|c|c}
\hline No. of Tests & $\begin{array}{c}\text { Mean of } \\
\text { Ceiling } \\
(\mathrm{mm} . \mathrm{Hg})\end{array}$ & $\begin{array}{c}\text { Standard } \\
\text { Deviation } \\
(\delta)\end{array}$ & $\begin{array}{c}\text { Possible } \\
\text { Ceiling in } \\
\text { Healthy Eyes } \\
(\mathbf{M}+3 \delta) \\
\mathrm{mm} . \mathbf{H g}\end{array}$ & $\begin{array}{c}\text { Definite } \\
\text { Pathological } \\
\text { Ceiling } \\
(\mathbf{M}+3 \delta+1) \\
\mathrm{mm} . \mathbf{H g}\end{array}$ \\
\hline 100 & $19 \cdot 1$ & $\pm 4 \cdot 1$ & $31 \cdot 4$ & $32 \cdot 4$ \\
\hline
\end{tabular}

The values of outflow facility for the 100 normal eyes in the supine position (C1) and in the $-25^{\circ}$ position (C2) with their percentage difference ( $\Delta$ per cent.) are set out in Table IV.

As shown by the values contained in Table IV, in all subjects we found a decrease in outflow facility, the extent of which ranges between 13 per cent. and 32 per cent. of the initial value of $C$. The average fall was 22.3 per cent. with a standard deviation $(\delta)$ of 4.4. Using the same statistical methods as for the tensional values, we have calculated the percentage decrease in outflow facility to be considered probably pathological (31 per cent.) and the percentage decrease to be considered definitely pathological $(35.5$ per cent.). These figures are set out in Table V.

For the outflow facility we preferred to apply statistics on percentage values rather than on absolute values, because of the considerable dispersion of normal $\mathrm{C}$ values $(0.15$ to 0.45 and over) in comparison to those considered as pathological $(0 \cdot 10 / 0 \cdot 15$ to 0$)$. 
POSTURAL TONOGRAPHIC TEST IN GLAUCOMA

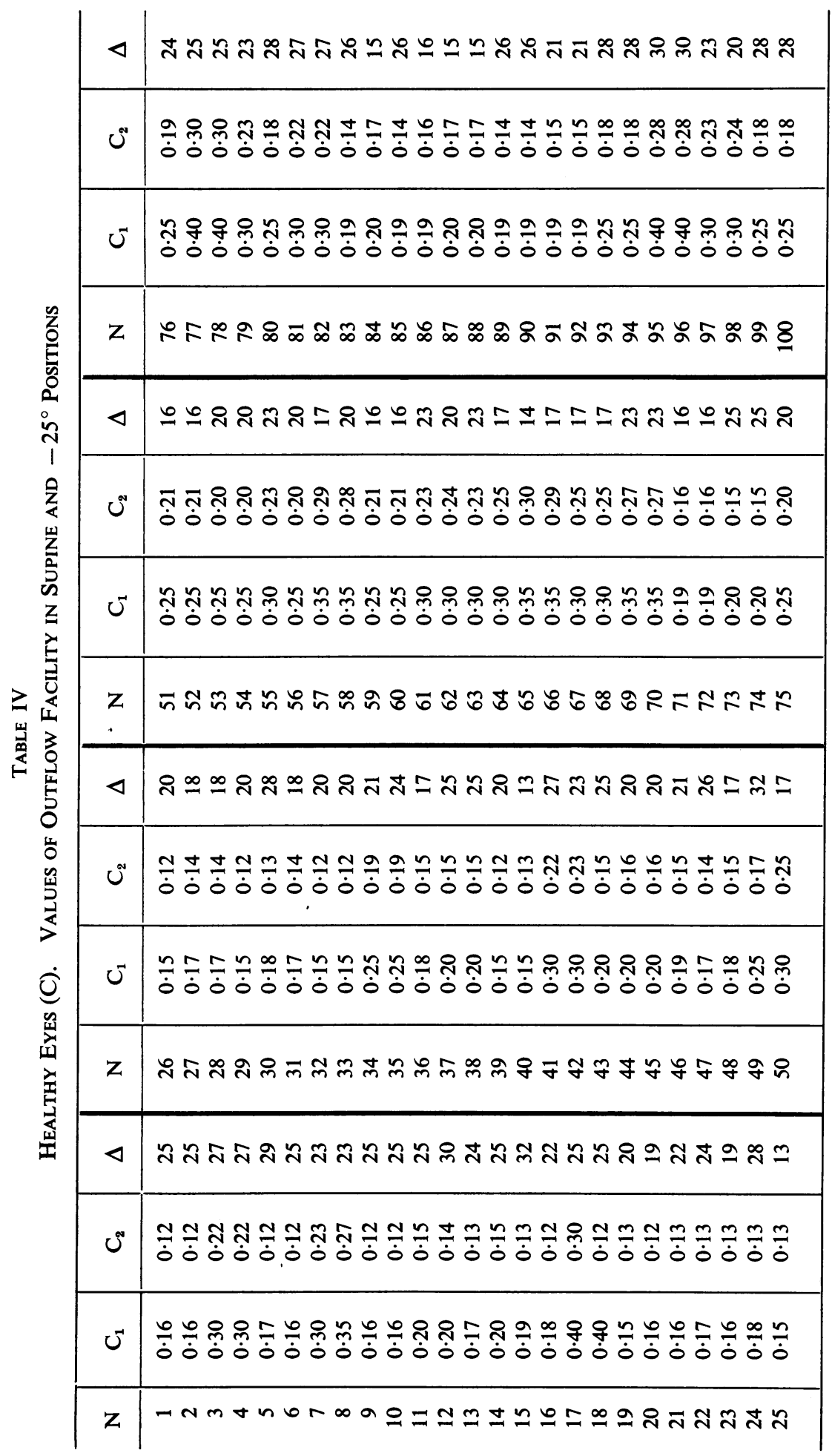


TABLE V

Percentage Decrease in Outflow

\begin{tabular}{c|c|c|c|c}
\hline No. of Tests & $\begin{array}{c}\text { Mean of } \\
\text { Decrease } \\
\text { of C } \\
\text { (Per cent.) }\end{array}$ & $\begin{array}{c}\text { Standard } \\
\text { Deviation } \\
(\delta)\end{array}$ & $\begin{array}{c}\text { Probable } \\
\text { Pathological } \\
\text { Decrease } \\
\text { (Per cent.) } \\
(\mathbf{M}+2 \delta)\end{array}$ & $\begin{array}{c}\text { Definite } \\
\text { Pathological } \\
\text { Decrease } \\
\text { (Per cent.) } \\
(\mathbf{M}+3 \delta)\end{array}$ \\
\hline 100 & $22 \cdot 3$ & $\pm 4 \cdot 4$ & $31 \cdot 1$ & $35 \cdot 5$ \\
\hline
\end{tabular}

If we had not used percentage values our calculation would have been noticeably influenced by this difference in dispersion; in fact, if we consider, for instance, a 0.40 to 0.35 variation of $C$ and a 0.15 to 0.10 variation of $C$, in both cases the difference in numerical values is 0.05 , but in the first case it is only of 12 per cent. while in the second case it is over 30 per cent., and the value of $\mathrm{C}$ passes from the limit of normality $(0 \cdot 15)$ to one considered glaucomatous $(0 \cdot 10)$.

After having thus established the normal limits of tensional and outflow facility variations from the application of the test on subjects with normal eyes, we established its sensitivity by determining the percentage of positive results on a number of glaucomatous subjects.

Table VI shows the tension values for the 100 glaucomatous subjects in the supine position (T1) and in the $-25^{\circ}$ position (T2) as well as their difference $(\Delta)$. In the $R$ column we also indicate the response to the test (negative $(N)$, positive $(P)$, and probably positive (PP)) on the basis of the certainly pathological and probably pathological values of increase found in the series of normal eyes.

By the same method, in Table VII we show the values of outflow facility in the supine position $(\mathrm{C} 1)$ and in the $-25^{\circ}$ position (C2), their respective percentage difference ( $\Delta$ per cent.) and the result of the test (negative, $(N)$ positive $(P)$, and probably positive (PP)).

As shown in Table VI, considering only the tensional values, out of 100 glaucomatous eyes examined 41 gave a negative response, 42 a positive, and 17 gave a probably positive response to the test. Considering the outflow facility value the same eyes (Table VII) gave 21 negative responses, 70 positive responses, and 9 probably positive responses.

These figures, indicated in a percentage form in Table VIII, show that the postural test applied to the above-mentioned procedures, even if limited only to the study of

TABLE VIII

Percentage of Outflow Facility Values

\begin{tabular}{c|c|c|c|c}
\hline & $\begin{array}{c}\text { Negative } \\
\text { Responses } \\
\text { (N) } \\
\text { (per cent.) }\end{array}$ & $\begin{array}{c}\text { Positive } \\
\text { Responses } \\
\text { (P) } \\
\text { (per cent.) }\end{array}$ & $\begin{array}{c}\text { Probably } \\
\text { Positive } \\
\text { Responses } \\
\text { (PP) } \\
\text { (per cent.) }\end{array}$ & $\begin{array}{c}\text { Total } \\
\text { of } \\
\mathbf{P}+\text { PP } \\
\text { (per cent.) }\end{array}$ \\
\hline T & 41 & 42 & 17 & 59 \\
\hline C & 21 & 70 & 9 & 79 \\
\hline
\end{tabular}




\begin{tabular}{|c|c|c|}
\hline & $\propto$ & 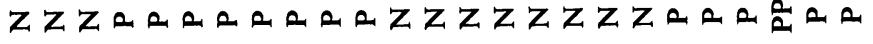 \\
\hline & $\triangleleft$ & 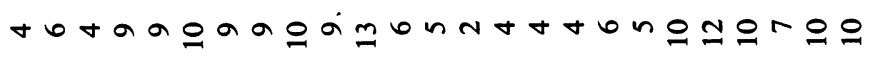 \\
\hline & $\stackrel{2}{*}$ & 官 \\
\hline & $\vec{H}$ & মัสิ \\
\hline & $\mathbf{z}$ & 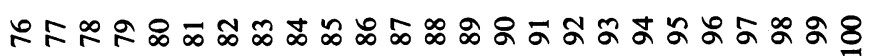 \\
\hline E & $\propto$ & 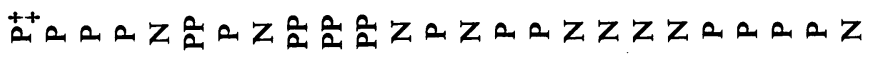 \\
\hline$\dddot{\sim}$ & $\triangleleft$ & 응aㅁNrrrtabaabt+to으의 \\
\hline $\mathrm{Z}$ & $\stackrel{n}{n}$ & డ్ల ర్లో \\
\hline$\vec{n}$ & $H$ & స \\
\hline & $\mathbf{z}$ & 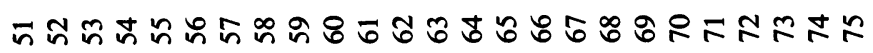 \\
\hline 造 & $\simeq$ & 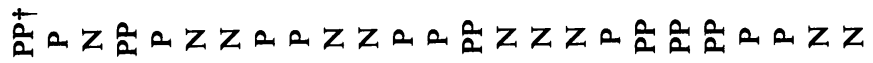 \\
\hline 兽 & $\triangleleft$ & 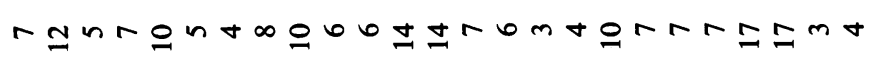 \\
\hline$\underbrace{E}_{\infty}$ & 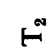 & జి \\
\hline 2 & $H$ & 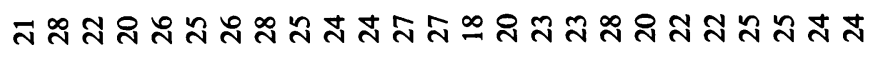 \\
\hline 8 & $\mathbf{z}$ & 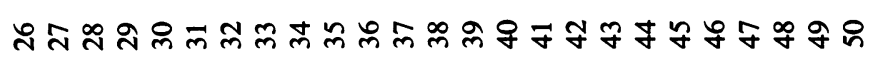 \\
\hline 5 & $\propto$ & 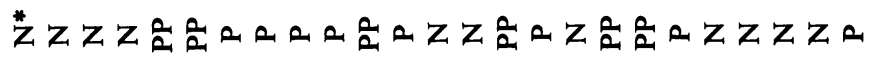 \\
\hline & $\triangleleft$ & 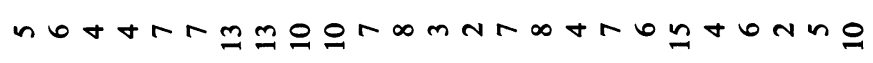 \\
\hline & $\stackrel{1}{*}$ & 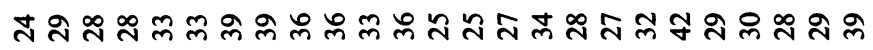 \\
\hline & $\vec{H}$ & 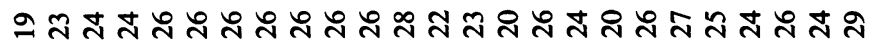 \\
\hline & $\mathbf{z}$ & 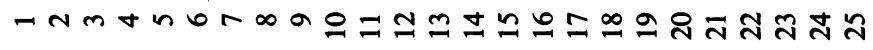 \\
\hline
\end{tabular}




\begin{tabular}{|c|c|c|}
\hline & $\propto$ & 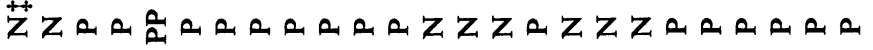 \\
\hline & $\triangleleft$ & 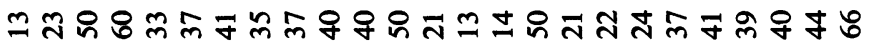 \\
\hline & $U^{*}$ & 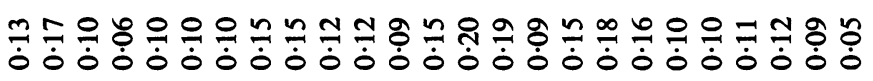 \\
\hline & $\vec{u}$ & 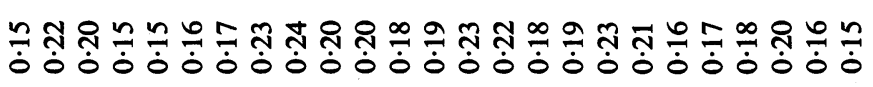 \\
\hline 5 & $\mathbf{z}$ & 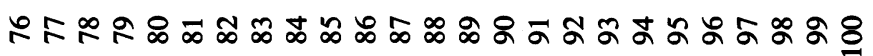 \\
\hline$\stackrel{i}{n}$ & $\approx$ & 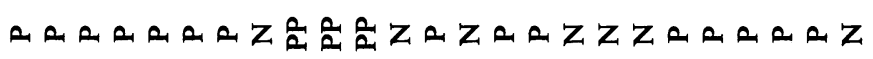 \\
\hline 昰 & $\triangleleft$ & 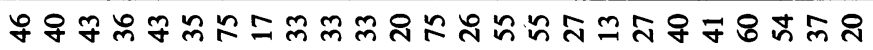 \\
\hline 崖 & Ũ & 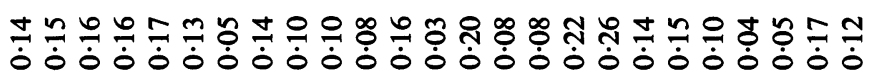 \\
\hline & $\dot{v}$ & 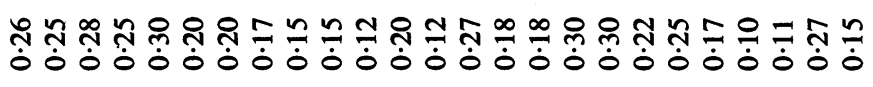 \\
\hline$=$ & $\mathbf{z}$ & 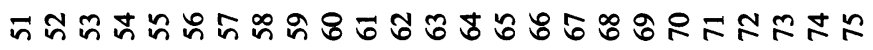 \\
\hline 要堅 & $\simeq$ & 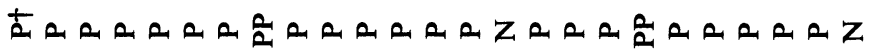 \\
\hline 茨 & $\triangleleft$ & 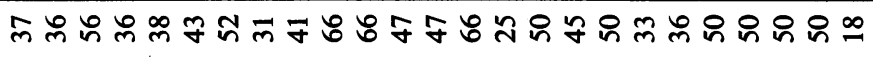 \\
\hline 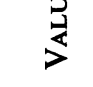 & Ũ & 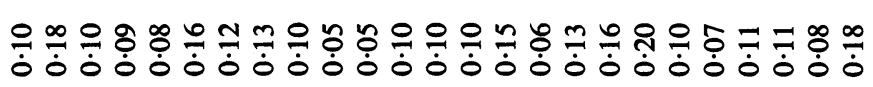 \\
\hline 商 & $\vec{v}$ & 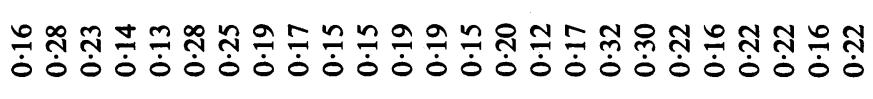 \\
\hline อ & $\mathbf{z}$ & 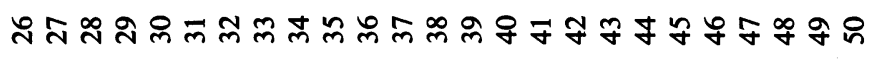 \\
\hline ) & $\simeq$ & 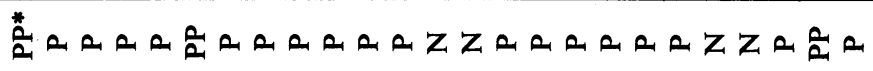 \\
\hline ט & $\triangleleft$ & ๓ \\
\hline & v & 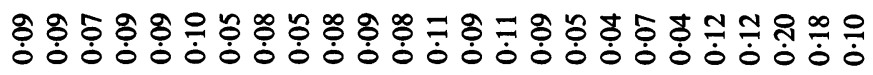 \\
\hline & $\dot{U}$ & 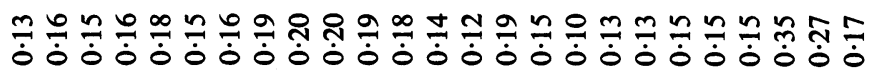 \\
\hline & $\mathbf{z}$ & 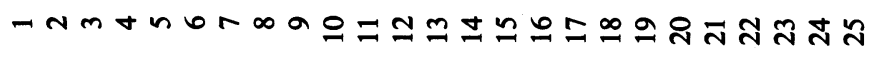 \\
\hline
\end{tabular}


pressure variations $(\mathrm{T})$ can be considered as valid (positive responses in 59 per cent. of cases). In fact, other widely used tests gave positive statistical results which are definitely lower; lability test, 14 per cent.; caffeine test, 15 per cent.; jugular compression test, 18 per cent.; homatropine test, 22 per cent.; water-drinking test, 33 per cent.; darkroom test, 54 per cent. (Leydhecker and Niesel, 1954; Leydhecker, 1955; Foulds, 1959). Only the Vasculat test (69 per cent.), the Blaxter test (73 per cent.), and the Sugar test ( 84 per cent.) have positive results in a greater number of cases (Andreani, 1954; Leydhecker, 1955), but they notoriously require special co-operation and stoicism by the patient.

Furthermore, the postural test together with tonographic examination (C) gives positive responses in an even greater number of cases ( 79 per cent.), thus confirming that the study of outflow facility as well as of tension increases the reliability of provocative tests. This fact had already been noticed by other authors in respect of other tests (Becker, 1956; Foulds, 1956; and Fanta, 1961).

With regard to the mechanism of the test, we believe that the tension increase is caused by an increase in venous pressure of the neck and head areas (episcleral veins included: Linner, Rickenbach, and Werner, 1950; Leith, 1963), and consequent decrease in outflow facility, as we have demonstrated by tonography. In normal eyes, owing to the presence of homeostatic reflexes which are now commonly recognized, an increase in outflow resistance produces a decrease in the rate of aqueous production which partly compensates for the increase (Becker and Constant, 1955; Weekers, Delmarcelle, Prijot, and Lavergne, 1957; Leydhecker, 1960).

The values of $F$ (rate of aqueous flow) for normal and glaucomatous eyes are shown in Tables IX and X.

Table XI summarizes the average values of $T_{1}, T_{2}, C_{1}, C_{2}, F_{1}, F_{2}$, and the relative percentage differences of normal and glaucomatous eyes. It is seen that the average tension increase caused by the test in normal subjects is relatively small (13 per cent.) and is conspicuous in glaucomatous eyes ( 31 per cent.).

TABLE XI

Average Values for Healthy and Glaucomatous Eyes

\begin{tabular}{c|c|c|c|c|c|c|c|c|c}
\hline & $T_{1}$ & $T_{2}$ & $\begin{array}{c}\Delta \\
\text { per cent. }\end{array}$ & $\mathrm{C}_{1}$ & $\mathrm{C}_{2}$ & $\begin{array}{c}\Delta \\
\text { per cent. }\end{array}$ & $\mathrm{F}_{1}$ & $\mathrm{~F}_{2}$ & $\begin{array}{c}\Delta \\
\text { per cent. }\end{array}$ \\
\hline $\begin{array}{c}\text { Means of healthy } \\
\text { eyes }\end{array}$ & 16.8 & 19.1 & $+13 \cdot 7$ & 0.236 & 0.185 & -22.1 & 3.60 & 3.05 & -15.2 \\
\hline $\begin{array}{c}\text { Means of glauco- } \\
\text { matous eyes }\end{array}$ & 24.1 & 31.7 & +31.5 & 0.190 & 0.113 & -40.5 & 3.89 & 3.02 & -22.3 \\
\hline
\end{tabular}

In normal eyes the decrease of outflow facility is 22 per cent. of the initial value, while the decrease of the aqueous flow is 15 per cent. In glaucomatous subjects this difference was much greater, in fact, a 40 per cent. reduction of $C$ corresponded only to a 22 per cent. reduction of $F$, with a consequently greater tensional increase.

It therefore seems possible that in glaucomatous eyes the test operates in a double way through the increase in outflow resistance and the lack of homeostatic reflexes which normally regulate the aqueous outflow. 


\begin{tabular}{|c|c|c|}
\hline & $\triangleleft$ & 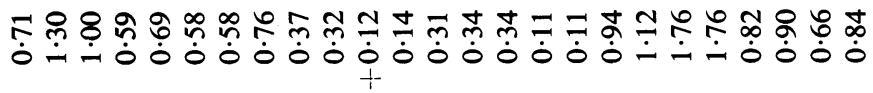 \\
\hline & $L^{N}$ & 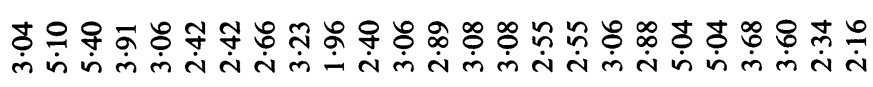 \\
\hline & $\omega^{-1}$ & 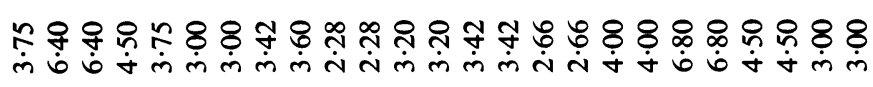 \\
\hline & $\mathbf{Z}$ & 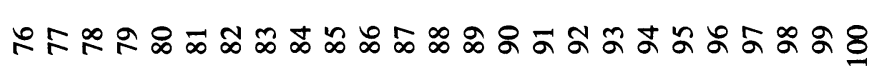 \\
\hline & $\triangleleft$ & 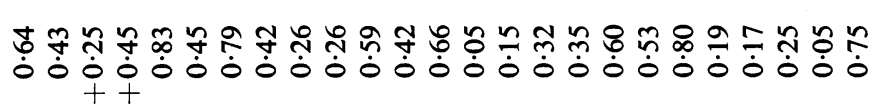 \\
\hline 党 & $\mu^{2}$ & \\
\hline$\frac{D^{0}}{2}$ & $L^{-1}$ & 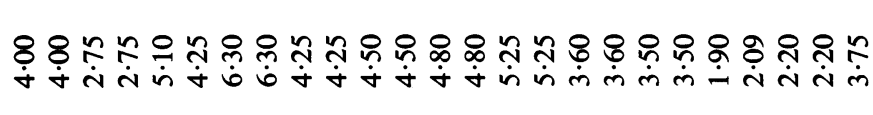 \\
\hline$\underset{x}{x}$ & $\mathbf{z}$ & 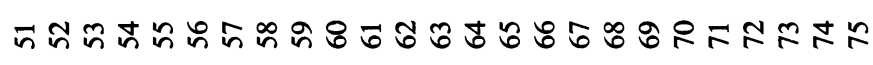 \\
\hline 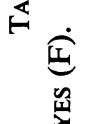 & $\triangleleft$ & 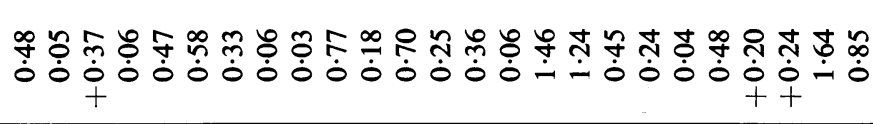 \\
\hline 崖 & $L_{1}^{\infty}$ & 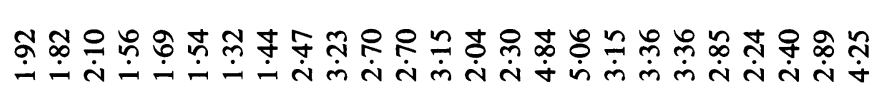 \\
\hline & $\omega^{-1}$ & 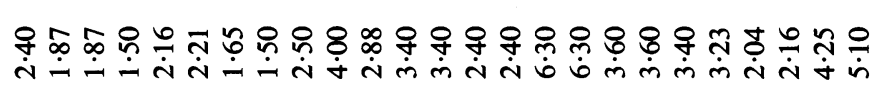 \\
\hline & $\mathbf{z}$ & 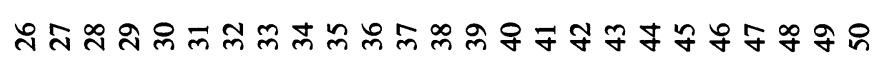 \\
\hline & $\triangleleft$ & 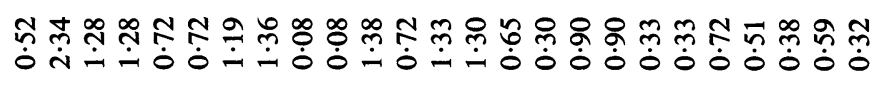 \\
\hline & $\check{L}^{\infty}$ & 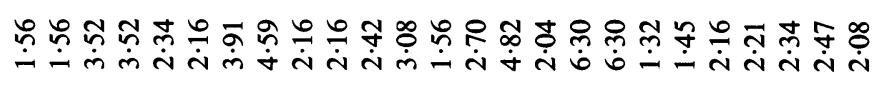 \\
\hline & 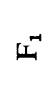 & 䎹 \\
\hline & 2 & $n+n 6 r \infty a 0=$ \\
\hline
\end{tabular}




\begin{tabular}{|c|c|c|}
\hline & $\triangleleft$ & 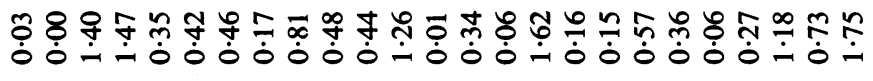 \\
\hline & $L^{N}$ & 붕 \\
\hline & $L^{-1}$ & 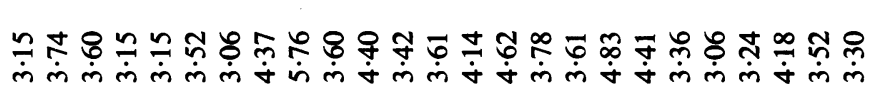 \\
\hline & $\mathbf{z}$ & 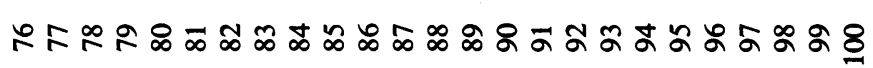 \\
\hline & $\triangleleft$ & 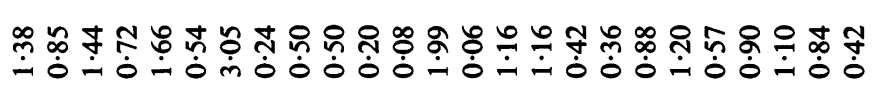 \\
\hline 至 & $L^{N}$ & 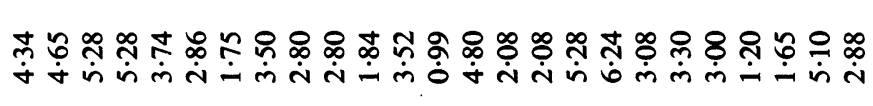 \\
\hline$\underset{4}{0}$ & $\omega^{-1}$ & 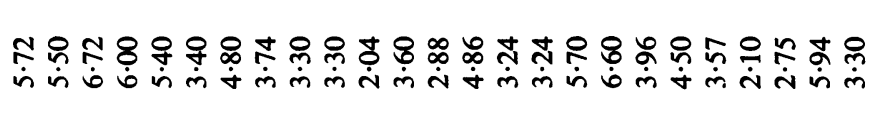 \\
\hline$\underset{\underline{\mu}}{x}$ & $\mathbf{z}$ & 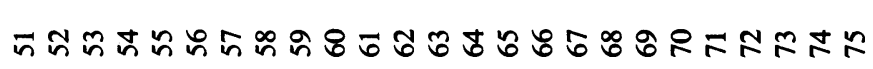 \\
\hline 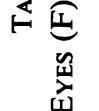 & $\triangleleft$ & 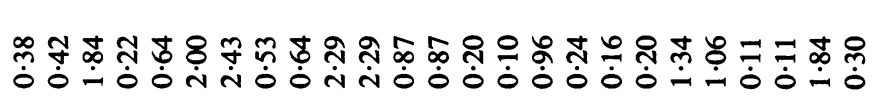 \\
\hline$\sum_{\substack{0 \\
0}}^{\infty}$ & $\omega^{N}$ & 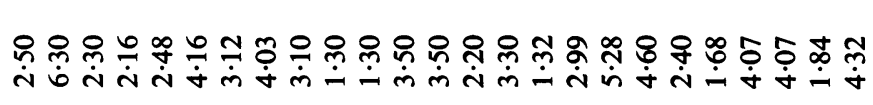 \\
\hline \ن & W" & 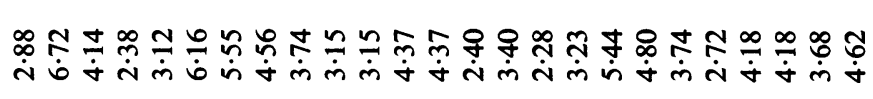 \\
\hline & $\mathbf{z}$ & 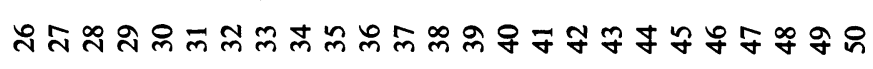 \\
\hline & $\triangleleft$ & 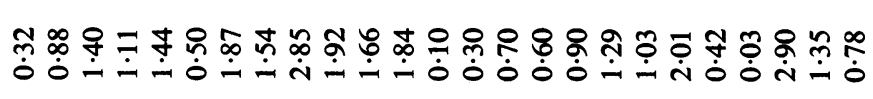 \\
\hline & $L^{\infty}$ & 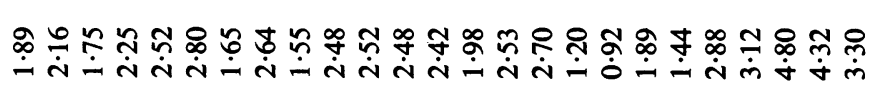 \\
\hline & $\omega^{-1}$ & तె \\
\hline & $\mathbf{Z}$ & 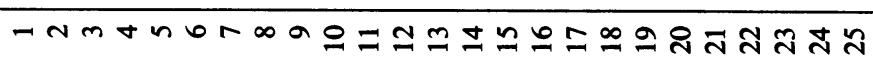 \\
\hline
\end{tabular}


On the basis of the data we have gathered on normal and glaucomatous eyes, as well as on their statistical evaluation, we can conclude that the postural test with the indicated procedure can be usefully applied in the early diagnosis of glaucoma, since it is reliable and requires only simple equipment and average patient co-operation.

\section{Summary}

A postural tonographic provocative test for the early diagnosis of glaucoma is described; a tonography is performed on the subject in the supine position and a second tonography on the subject inclined $25^{\circ}$ head-downwards. A period of at least twenty-four hours is allowed to elapse between the two tonographic examinations, and for each patient these examinations are performed at the same hour. The values of $\mathrm{T}, \mathrm{C}$, and $\mathrm{F}$ for the two examinations are considered.

After having established the normal limits of tensional and outflow facility variations due to the test on 100 normal eyes, we have studied the sensitivity of the test by determining the percentage of positive results on 100 eyes with chronic simple glaucoma in 73 patients.

The results were statistically analysed, and the mechanism of the test discussed.

We feel that the postural tonographic test with its 79 per cent. of positive responses can be usefully applied in the early diagnosis of glaucoma, since it is more statistically reliable than many other widely used tests and requires only simple equipment and average patient co-operation.

The authors wish to thank Dr. Antonio Grignolo, Professor of Ophthalmology, University of Genoa, for his suggestions and support throughout the whole of this work.

\section{REFERENCES}

ANDREANI, D. (1954). Ann. Ottal., 80, 261.

Ballintine, E. J. (1954). Acta XVII Congr. Ophthal., Canada-U.S.A., vol. 3, p. 1516.

BeCKer, B. (1956). Eye, Ear, Nose Thr. Monthly, 35, 249.

and Constant, M. A. (1955). A.M.A. Arch. Ophthal., 54, 321.

Boles Carenini, B., and Molfino, A. (1961). Ann. Ottal., 87, 149.

CASelli, F. (1954). Arch. Ottal., 58, 67.

EBISAWA, K. (1956). J. clin. Ophthal. (Tokyo), 10, 1031.

FANTA, H. (1961). Klin. Mbl. Augenheilk., 138, 498.

Foulds, W. S. (1956). Trans. ophthal. Soc. U.K., 76, 83.

(1959). Brit. J. Ophthal., 43, 697.

KöLLNER, H. (1916). Arch. Augenheilk., 81, 120.

Комото, S. (1954). Acta XVII Congr. Ophthal., Canada-U.S.A., vol. 2, p. 959.

LEITH, A. B. (1963). Brit. J. Ophthal., 47, 271.

LEYDHECKER, W. (1950). Ibid., 34, 535.

- (1955). In "Glaucoma-a Symposium", ed. S. Duke-Elder, p. 205. Blackwell, Oxford. (1960). "Glaukom: ein Handbuch". Springer, Berlin.

- and MeINKE, A. (1956). Arch. Soc. oftal. hisp.-amer., 16, 348.

- and Niesel, P. (1954). Klin. Mbl. Augenheilk., 125, 458.

LINNER, E., RiCKENBACH, C., and WERNER, H. (1950). Acta ophthal. (Kbh.), 28, 469.

Moses, R. A., and BeCKer, B. (1958). Amer. J. Ophthal., 45, 196.

SCHARF, J. (1952). Ber. ophthal. Ges., 57, 212.

Stroble, G., and FollmanN, P. (1936). Acta chir. Acad. Sci. hung., 3, 411.

Tessier, G. (1930a). Lett. oftal., 7, 383.

- (1930b). Ibid., 7, 311.

THIBERT, R. (1922). Arch. Ophthal., 39, 437.

THIEL, R. (1925). Arch. Augenheilk., 96, 331.

Weekers, R., Delmarcelle, Y., PriJot, E., and Lavergne, G. (1957). Amer. J. Ophthal., 43, 899.

WEGNER, W. (1925). Z. Augenheilk., 55, 381. 